Ana Miljević*

Filozofski fakultet

Univerzitet u Novom Sadu
UDK 1 Homer 17.023.33:621.3.016

DOI: $10.19090 /$ gff.2017.2.47-58

Originalni naučni rad

\title{
ODREĐENJE ŽIVOTNE SNAGE U HOMEROVIM EPOVIMA
}

Ontološki dualizam duha i tela nalazi svoje korene u antici, te ovaj rad istražuje da li i u kom kontekstu možemo da ga prepoznamo u epskom pesništvu osmog i sedmog veka pre n.e. Osnovnu tezu, prethodnih studija zastupljenih u literaturi, da se u homerovskoj psihološkoj terminologiji kriju pitanja o poreklu i prirodi duše i o potonjem razlikovanju duše od tela, ovaj rad vidi kao posledicu metafizičke redukcije pojma životne snage, a ne kao izvorno homerovsko pitanje. Stoga se vraćam supstancijalnom jedinstvu pojma životne snage u Homerovoj epskoj poeziji da bih utvrdila bogatu terminološku neusklađenost u kojoj se jasno pokazuju prva objašnjenja kretanja i pokretačkih sila neodvojivih od predstava o životu i smrti. U radu se vrši klasifikacija termina koji opisuju životnu snagu na: životnu snagu srčanosti, životnu snagu sagledavanja i životnu snagu udova. Otuda rad termine $\tilde{\eta} \tau o \rho$,

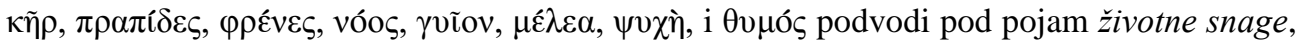
a ne pod psihološku terminologiju, što omogućava da se razume potonja povezanost $\psi v \chi \grave{\eta} i$ $\zeta \omega \eta$ i napravi put ka filozofiji prirode ranih predsokratovaca.

Ključne reči: Homer, životna snaga, phrenes, ethor, noos, psyche, thymos, soma, melea.

\section{UVOD}

Kako je zato neizrecivo uzvišen Homer koji se, kao pojedinac, prema apolonskoj narodnoj kulturi odnosi kao pojedini umetnik-sanjar prema sanjarskoj sposobnosti naroda i prirode uopšte.

O čemu sanja Homer “umetnik-sanjar”? Ukroćenu silovitost srdžbe tesalskog kralja Ahileja božanskim glasom mudre Atine? Potres usana kralja Prijema dok ljubi ruku koja je smrti privela mu sina? Pogreb požrtvovanog Hektora čiji leš skrnavi Ahilejeva žar za osvetom? O smrti najmilijeg prijatelja Patrokla? San Angamemnonov ili lepu Brizeidu? Homer privodi pesmi "sanjarsku sposobnost naroda i prirode uopšte“, sažima suprotnost apolonovskog i dionizijskog u

\footnotetext{
*anamiljevic@ff.uns.ac.rs
} 
jedinstvo svog grčkog duha, snagom mita opisuje životnu snagu grčkog junaka. One, snaga mita i životna snaga su u Homerovim epovima i himnama u saglasju, postaju opšte, važe za sve, za duh i telo. One, zapravo uopšte ne poznaju nikakav ontološki dualizam. Ako je, pak, ovo neraspoznavanje odlika naivnosti, onda ta naivnost nosi u sebi uzavrelo bogatstvo reči iz koji se rađaju pojmovi presokratovske filozofije.

Zadatak ovog rada je da pokaže tananost pojma životne snage u Homerovom pesništvu, tananost koje se odrekao mladi Platon, da bi joj se kao starac vratio. Mišljenja smo da se $u$ terminologiji životne snage nalaze prva objašnjenja kretanja i pokretačkih uzroka, prvi pokušaji mišljenja u apstraktnom. To ne znači, a to treba kao prvo naglasiti da se pojam životne snage u Homerovom epovima misli kao početak, ili uspostavljanje, ili na bilo koji način govor o jedinstvu duha i tela. Jedinstvo u punom smislu te reči je uvek dijalektičko, ono uvek već pretpostavlja razliku. I ne samo to. Ukoliko bi, na osnovu prethodno rečenog, ustvrdili da ako i ne postoji jedinstvo duha i tela, onda svakako Homer ne pravi ni među njima razliku, takođe bi bili na krivom putu. Jer mi možemo da govorimo o razlikovanju (ili nerazlikovanju) dva pojma, samo s obzirom na granicu kojom prvo utvrđujemo njihovo značenje unutar njih samih. Ukoliko pojam nije u sebi determinisan (a smatramo da Homer još nema jedinstvenu predstavu niti o telu, niti o duši/duhu), nemamo prava na ovo kategorisanje, a čini se da i sa samim određenjem životne snage nailazimo na ovaj problem. U ovome leži obrazloženje za naziv rada, jer on nije naslovljen tako da se pretpostavlja da Homer ima predstavu duše i tela, ili da razume njihove funkcije kao njihove osobenosti. Opredeljujući se za termin "životna snaga" pokušali smo da izbegnemo teškoće koje pred nas stavlja moderno kategorisanje, a da u isto vreme objedinimo niz termina, koji životnu snagu manje ili više uspešno opisuju. Svrha ovog rada je da pokaže da se kroz terminologiju životne snage otvara put kojim otpočinje filozofija, put filozofije prirode. Stoga, metod kojim se rukovodimo u radu nije samo analitički, već i dijahronički i hermeneutički. Njegov filološki aspekt je prisutan zbog same prirode Homerovog jezika, ali nije presudan u zaključivanju.

\section{NAČINI IZRICANJA ŽIVOTNE SNAGE U ILIJADI I ODISEJI}

Događaji koji se otkrivaju u Ilijadi i Odiseji u sebi nose razumevanje života i one pokrećuće snage kojom život jeste i kojom se ospoljava. Otuda je pojam životne snage neraskidivo povezan sa predstavama o životu i smrti, te životu nakon smrti iz kojih neposredno izvire. Prehomerovski helenski duh izgrađen na kultu predaka, nosio je u sebi, ono naglašeno i u epici osmog i sedmog veka, iskonsko 
osećanje (meta)fizičnosti sveta i čoveka, tako duboko skriveno u razumevanju sudbine kao one neopažajne, apstraktne sile koja vlada čovekovim životom i smrću.

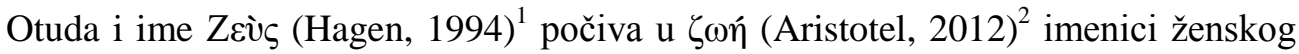
roda, a kod Homera ime Zevsa nalazimo istoimeno sa kontrahovanim glagolom $\zeta \tilde{\eta} v$.

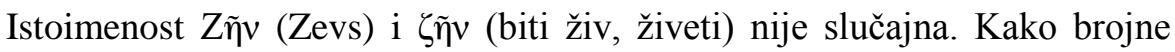
studije pokazuju "etimološki metod" pri određivanju imena bogova je bio omiljen u starini, pa je do preuzimanja skraćenog oblika možda i došlo usled ove istoimenosti, a to za nas znači da je život Homerovog čoveka usmeren na božansko, da svoju snagu crpe iz božanskog, te da božansko upravlja njime koji je smrtan. To je toliko, i na suštinski način prisutno u grčkom duhu da će Platon u Fedonu svoj drugi dokaza o besmrtnosti duše, da bazira na ovom stavu, smatrajući ga po sebi istinitim (Plat. Phaedo, 80). ${ }^{3}$ Ukoliko je božansko po prirodi ono koje vlada (ä $\left.\rho \chi \varepsilon ı v\right)$ onda ono nad čim vlada, a kod Homera je to gotovo uvek čovek, ne poznaje sopstvene odluke kao izraz vlastite životne snage, već njen izvor nalazi izvan sebe. Ovog stanovišta je Snel koji u svom delu Die Entdeckung des Geistes kaže: "Jede Mehrung der körperlichen und geistigen Kräfte geschieht von außen, vor allem durch die Gotterheit." (Snell, 1975: 28). Izvedeno to bi značilo da je u Homerovim epovima životna snaga izmeštena van čoveka kao prirodnog bića, da ga na neki način transcendira, sa čim ne možemo da se složimo. Naime, bogovi Homerovih

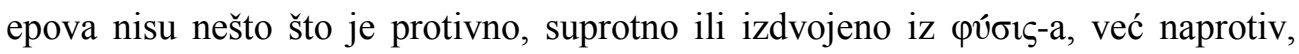
njihov svet je izraz $\varphi v ́ \sigma ı \varsigma-a$, svet iz čije će uređenosti da izraste pojam kosmosa u kome će geometrijski poredak da označava pravdu i njenu granicu. Tim pre možemo reći, da Homer životnu snagu razume kao ovaj izraz prirodnog koji je u epici osmog i sedmog veka pre nove ere ništa drugo do izraz božanskog. Suprotno od očekivanog zaključka da životna snaga homerovskog čoveka dolazeći od bogova ima svoje poreklo u onostranom, treba razumeti da se ,in den homerischen

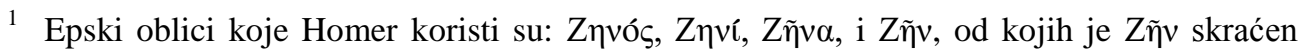
akuzativ osnove $\Delta$ ınv onog božanskog.

${ }^{2}$ Vidi: 415a 10- 416a, 416b 9-30. O odnosu duše i živog tela u Aristotelovoj psihologiji je bilo reči u prethodnom zapažanju. S. Blagojević u svojim komentarima str.125 na odeljak 412a 8 Aristotelovog spisa $O$ duši smatra da se "Aristotelova implicitna identifikacija duše i načela života u svim njegovim oblicima može shvatiti pre kao formulacija teze jedne sveobuhvatne filozofije života koja svoje središte ima u pojmu duše.” str.125. Potvrdu

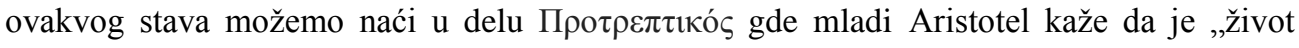
svakom živom biću isto što i bitak“" (str. 132.)

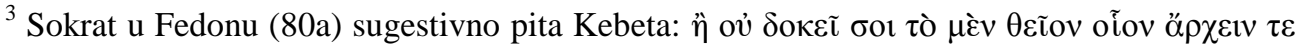

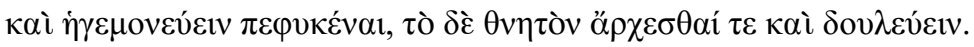


Gedichten tritt dieses „Natürliche“ zum ersten Male in die Welt, und zwar so, daß die „natürliche Existenz“ des Menschen gebunden ist an das Sinnvolle im Dasein der Götter.“(Snell, 1975 :41)

Čini se da bi to moglo da bude objašnjenje zašto Homerovi epovi donose višeznačno razumevanje životne snage koje se samo u pojedinim segmentima, i

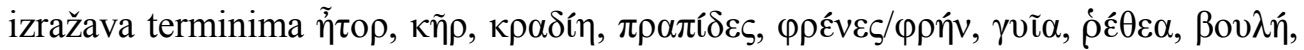

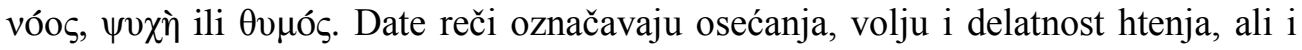
zapažanja i prosuđivanja koji su po pravilu „u-telovljeni“, što kod Homera još znači da je njihova funkcija istovetna sa funkcijom nekog od organa (Snell, 1975), ali ne i da se ove snage nalaze u telu kao celini. Međutim, smatramo da bi podjednako tačno bilo reći da Homer pomenutim izrazima označava funkciju nekog od organa ili sam taj organ (srca, jetre, dijafragme, mišića, kosti, zgloba, vida, etc.), koji po pravilu u njegovom epskom stihu imaju preneseno značenje, ili su čak istovetni sa pokretima, osećanjima, voljom ili naumom i mišljenjem, čime su uduševljeni.

Uzrok terminološke razuđenosti pojma životne snage možemo pronaći u karakteristikama epskog poetskog jezika koji je izgrađivan vekovima pre pojave Homera, a čiji vokabular ima drugačiji spektar značenja od onog koji je prisutan u govornom jeziku Homerovog doba, kako to smatra Darkus Saliven (Darcus Sullivan, 1987). U jednom smislu, oblast značenja termina koju nude Ilijada $i$ Odiseja upućuju na njegovu predhodnu upotrebu u epskom govoru i seže u praistoriju, u drugom, izrazi životne snage se udaljavaju od njene prevashodno fiziološke konotacije u ranijem epskom govoru, koji je predstavljao ,a limited picture of the scope of meaning of differet terms.“ (Darcus Sullivan, 1987: 183).

U literaturi koja se bavi filološkim i terminnološkim aspektom Homerovog pesništva se značenje pomenutih termina prepliće, ne samo u pogledu njihove fiziološke semantike, već i sa onim što mi danas nazivamo izrazima za određene psihološke funkcije. Klasifikacija koju iznosimo u ovom radu treba da nadvlada dati ontološki dualizam i da otvori put ka presokratovskoj filozofiji i problemu kretanja koji je u ranoj filozofiji prirode dominantan. Na osnovu toga možemo da razlikujemo tri osnovne terminološke grupe kojima je opisana životna snaga:

1. Z Životna snaga udova se u jednom smislu određuje terminima koji su vezani za fizičku pokretljivost, kao i onih koji u sebi

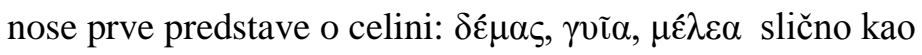

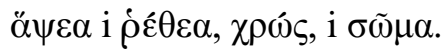

2. Drugu grupu, životnu snagu srčanosti, čine termini koji imaju gotovo sinonimnu upotrebu sa organom koji se nalazi u oblasti grudnog koša, a koji može biti srce ili njegova opna 


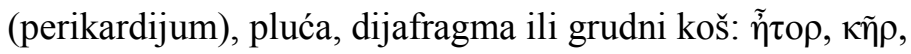

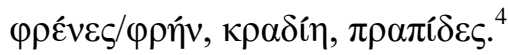

3. Z Životna snaga sagledavanja pokazana u terminima koji označavaju uviđanje, mišljenje i one opšte pokretačke snage

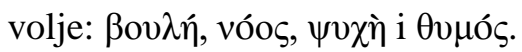

U navedenom semantičkom grupisanju uzeta je u obzir i upotreba reči nakon Homera, dakle, ,život" termina u širem smislu. Stoga, pojedini termini mogu zavisno od konteksta u kome se nalaze u Ilijadi i Odiseji, ali i od potonje upotrebe u živom govoru, koja u hermeneutičkom smislu doprinosi njihovom razumevanju da budu određeni dvoznačno, tj. da istovremeno budu deo različitih grupa. Među takvima se izdvaja $\theta 0 \mu o ́ s$, jer on naprosto pokriva značenje gotovo svih drugih navedenih termina, što znači da ga Homer sinonimno upotrebljava, i jednog drugim iz ritmičkih i stilskih razloga zamenjuje u izražavanju životne snage. Različiti pristupi homerskoj "psihološkoj terminologiji" ne uzimaju uvek u obzir jedinstvenost fenomena koji je pred nama, pa i zanemaruju sveobuhvatnost životne snage posredno je rastačući na psihičku i fizičku sferu. Tako za Jana termini koje smo mi odredili grupom životna snaga srčanosti uz dodatak $\theta v \mu o ́ s-a$, jedini pripadaju Wortfeld Seele-Geist i njihovo se značenje pruža i na spoznaju, za razliku

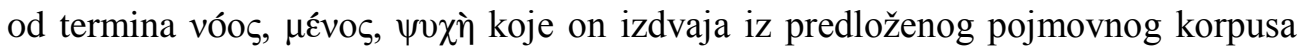
(Jahn, 1987). ${ }^{5}$ Time on dokazuje sinonimnu upotrebu $\theta 0 \mu o ́ \varsigma, ~ \tilde{\eta} \tau o \rho, ~ \kappa \tilde{\eta} \rho$,

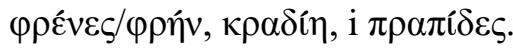

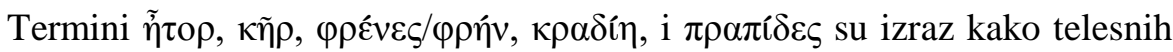
organa, tako i osećanja, volje ili htenja, često srdžbe, žustrine, siline uzbuđenja koji nisu tek uzgredna metafora, već način na koji čovek Ilijade i Odiseje jeste. Stoga, možemo reći da su oni lokalizovani u grudnom košu, samo ako razumemo da ta lokalizacija nije učinjena naknadno ili spolja, već da je ona organska. Ona je takva, utoliko što životna snaga ne transcendira ono pojedinačno koje je njen nosilac. Srčanost (osećanja, volja, htenja) je izjednačena sa srcem kao njenim nosiocem u pojedinačnom čoveku. Stoga smatramo da nije sasvim ispravno reći da Homer volju

${ }^{4} \mathrm{U}$ dva svoja rada Darkus Saliven posebno ističe sinonimnu upotrebu ovih termina za različite delove tela, a izgleda da je slaganje u ritmu bilo od presudne važnosti za Homerov odabir jednog od njih (Darcus Sullivan, 1987; 1988).

5 Jan to čini na osnovu određivanja dva pokazatelja onog psihičkog. Jedno je terminološko područje fizioloških faktora (Wortfelder Physische Faktoren) koji su označeni kao oni koji opisuju unutrašnji život čoveka, a drugo psihičkih doživljaja (Wortfelder Psychisches Geschehen), koje se odnose na dejstvo, tj. ospoljavanje unutrašnjih faktora (Jahn, 1987:8). 
ili osećanja utelovljuje u prsima. Naime, ona kao takva, kao jedna psihička funkcija sama po sebi nije ni moguća u svetu koji Homer stavlja pred nas.

Nerazlikovanje ,srca“ od žustrine, radosti, želje i uopšte siline uzbuđenja u

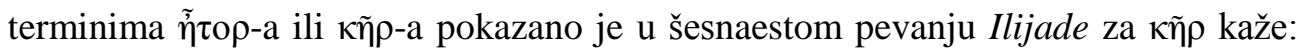

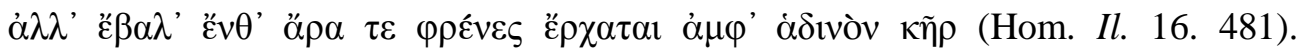
Analogno važi i za druge stihove u kojima se javlja termin $\kappa \tilde{\eta} \rho$, te njegov nešto

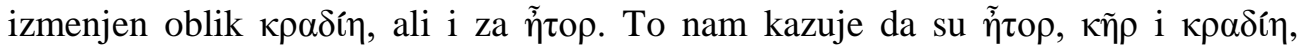
shvaćeni kako u fiziološkom tako i u psihičkom smislu današnjice. Rode navodi da nam ,pesnikove reči otkrivaju da on u stvari zamišlja bestelesnima nagone i uzbuđenja koja još nose imena prema delovima tela.“ (Rode, 1991: 37). Mi se ne možemo složiti sa ovim ne samo zato što pretpostavka zamišljanja bestelesnih funkcija od strane Homera protivreči samim Rodeovim postavkama, već zbog kauzalne veze koja je njome pretpostavljena. Naime, bol, tuga, radost prouzrokuju brži rad srca, povlačenje dijafragme etc., a ne obratno. U tom smislu, bilo bi ispravnije reći da su srce i njegove ovojnice u svojim fiziološkim funkcijama homerskom čoveku izgledali duševno. Oni su u homerskoj epici o-duševljeni u mnogo većoj meri nego što je to za naše današnje predstave dopustivo. Dakle nije reč, niti o fizičkoj, ni o fiziološkoj, niti o psihološkoj funkciji $\tilde{\eta} \tau o \rho-a$, već o životnoj

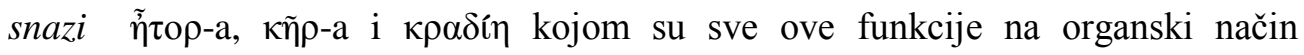
objedinjene, ili preciznije rečeno u kojoj se one još kao odvojeni segmenti bivstvovanja ne razlikuju. Ne razalikovanje proizilazi iz jedinstva događaja kojima su pobuđeni ili koje pobuđuju.

Upotreba $\varphi \rho \varepsilon ́ v \varepsilon \varsigma / \varphi \rho \eta ́ v ~ i ~ \pi \rho \alpha \pi i ́ \delta \varepsilon \varsigma$ ovo prvotno jedinstvo još jasnije pokazuje čime je njihova semantička zagonetnija. Većina tumača im pridružuju i $\theta v \mu o ́ s,{ }^{6}$ ali kako su njihova značenja u fiziološkom smislu mnogo bliskija od onog koji imaju sa $\theta v \mu o ́ \varsigma$ mi ga ostavljamo po strani. Dugo se pretpostavljala sinonimna upotreba $\varphi \rho \varepsilon ́ v \varepsilon \varsigma / \varphi \rho \eta ́ v$ i $\pi \rho \alpha \pi i \delta \varepsilon \varsigma$ u čijem kontekstu ova dva termina treba da razumemo kao opnu koja obavija i time odvaja organe utrobe jedne od drugih, nešto poput perikardijuma, maramice ili dijafragme, unutrašnja ovojnica, ${ }^{7} \mathrm{~s}$ tim da se kod Homera množina $\varphi \rho \varepsilon ́ v \varepsilon \varsigma$ češće pronalazi, što je znak da je možda u pitanju više

\footnotetext{
${ }^{6}$ U ovom radu se kasnije pokazuje zašto iako se čini se da spisku treba dodati i $\theta v \mu$ ó se u Ilijadi i Odiseji frekventivno smenjuje posebno sa $\pi \rho \alpha \pi i ́ \delta \varepsilon \varsigma$ više od 300 puta (Darcus Sullivan; 1996; 1987: 182) mi to i ne činimo.

${ }^{7}$ Etimologija reči $\pi \rho \alpha \pi i ́ \delta \varepsilon \varsigma$ nije do kraja razjašnjena. Bilo je sugestija koje su upućivale na lepotu, ali koje nisu prihvaćene. U sinonimnoj upotrebi $\varphi \rho \varepsilon ́ v \varepsilon \varsigma$ i $\pi \rho \alpha \pi i ́ \delta \varepsilon \varsigma$ po brojnosti prednjači $\varphi \rho \varepsilon ́ v \varepsilon \varsigma$, pri čemu kako je to Saliven pokazala, postoje sporne pretpostavke njihove sinonimnosti u značenju unutar-grudne maramice.
} 
različitih organa sa istom funkcijom. Na kraju i $\pi \rho \alpha \pi i \delta \varepsilon \varsigma$ je imenica u množini. Ukoliko postoji neka razlika među njima ona najverovatnije, kako je to Saliven pokazao, dolazi iz jezika pređašnje epike (Darcus Sullivan, 1987: 187). ${ }^{8}$

Semantika $\varphi \rho \varepsilon ́ v \varepsilon \varsigma$ i $\pi \rho \alpha \pi i ́ \delta \varepsilon \varsigma$ seže do "rasuđivanja" ili "dolaženja do smisla", čime se njihova semantika približava drugoj grupi u našoj klasifikaciji

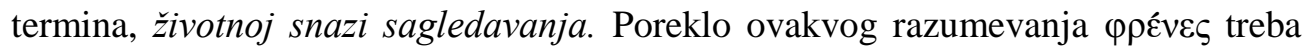
tražiti u stihovima koji $\varphi \rho \varepsilon ́ v \varepsilon \varsigma$ vezuju za prirodu bogova. Tako u devetnaestom pevanju Agamemnon Herinu prevaru koja pogađa Zevsa opisuje sledećim rečima

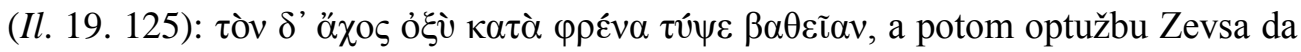

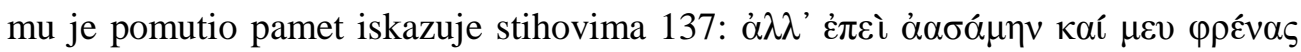

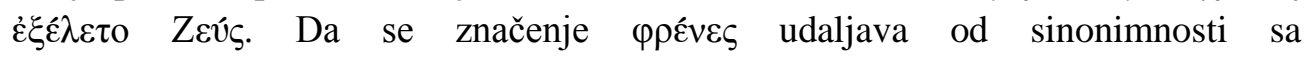
opnom/maramicom primećuje se i po terminu ö $\varphi \rho \omega v$. Otuda se $\varphi \rho \varepsilon ́ v \varepsilon \varsigma$ razvija u potonjoj Hesiodovoj epici, a nadalje i posebno u lirici 7. veka od životne snage srčanosti smeštene u grudima u još neodređenu vrstu rasuđivanja, u kojem svoje

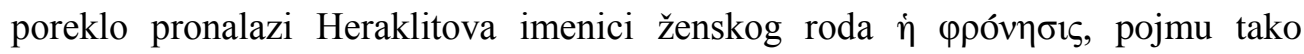
značajnom u filozofiji Aristotela (Snell, 1977).

Približavanje termina koji označavaju životnu snagu u Homerovoj epici svetu bogova, donosi obrt u samom sagledavanju tog sveta koje se osvedočuje u Odiseji. Već u prvim stihovima ovog epa očituje se promena koja nije samo one prirode koju nalazi Aristotel u Poetici (Aristotel, 1912: 56). Odnos bogova prema ljudima postaje drugačiji, a bogovi su sudionici u pravilnom postupanju ljudi više nego što je to bio slučaj u Ilijadi. Stoga, i neki termini ove grupe nisu samo odlika

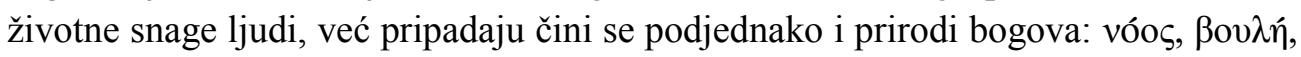

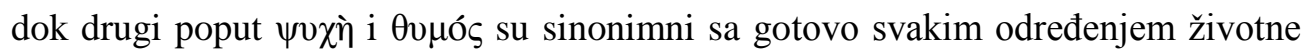
snage koji je u ovom radu naveden. Ovaj neznatni preokret ipak mnogo govori o „otkriću duha“ (die Entdeckung des Geistes) u ranoj grčkoj misli.

Za razliku od Homerovog prizivanja muza u Ilijadi kojim se najavljuje pevanje o srdžbi Ahileja, Odiseja već prvim stihovima najavljuje pevanje o junaku

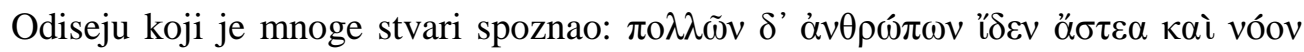

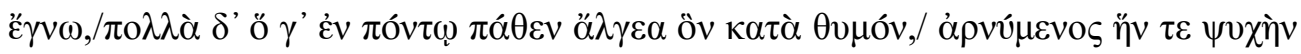

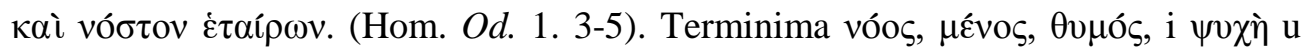

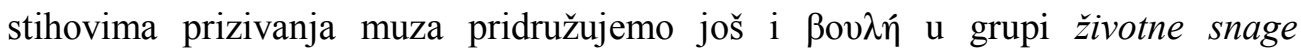
sagledavanja, pri čemu sa-gledavanje razumemo kao skriveno sabiranje smisla. Tek u tom najširem smislu ovi termini mogu da stoje zajedno.

${ }^{8}$ Saliven to dokazuje analizom glagola $̇ \dot{\pi} \psi \alpha u ́ \omega$ u odeljku iz Odiseje (Hom. Od. 8. 347-

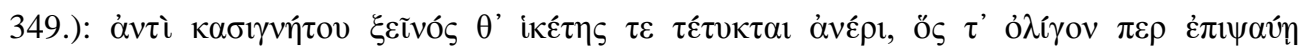
$\pi \rho \alpha \pi i \delta \varepsilon \sigma \sigma 1$. 
Sa-gledavanje nosi u sebi tu nerazdvojenost, to, rekli bismo organsko jedinstvo između oka kao organa koji posmatra svet spolja i funkcije unutrašnjeg vida. Svaki od navedenih termina okupljaju u sebi životnu snagu koja nije vezana za spoznaju kao takvu, ili bar ne jedino za spoznaju (spoznaja je tek učinak) ${ }^{9}$, već pre označavaju sabiranje događaja u unutrašnji, često skriveni, smisao. Sa-gledava se skriveno sabiranje smisla unutrašnjom životnom snagom, snagom skrivenom od spoljašnjeg posmatrača događaja. Treba ipak naglasiti, da mi pod sa-gledavanjem ne podrazumevamo razumsko saznanje, niti znanje koje pojedinac uči, dakle, spolja usvojeno upravo iz razloga skrivenosti.

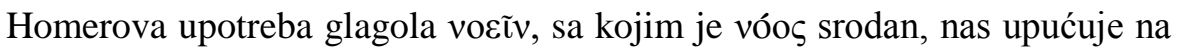
gledanje, čulno opažanje ili viđenje (von Fritz, 1943), ${ }^{10}$ čija radnja za razliku od srodnih glagola pretpostavlja i u-viđanje, sabiranje iskustva, i promišljanje, pa otuda ne čudi da se Homerova upotreba voeĩv i vóos razvila do Platona u zreo filozofski pojam voũ s značenje uma. I ne samo da začetke Platonovog pojma voũ $\varsigma$-a tako veličanstveno opisanog u sedmoj knjizi Države možemo pronaći kod Homera, već i

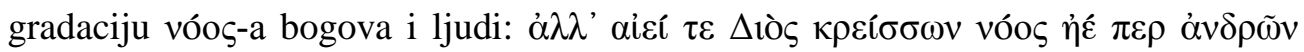
(Hom. Il. 16.688), gradaciju koja će u potonjoj filozofskoj misli čini se da posluži za mnoge epistemološke distinkcije.

Ali ova funkcija dolaženja do smisla voũ - -a je kako to pokazuje filološka analiza kroz reakciju sa glagolima Darkus Saliven bitno drugačija od one koju ima

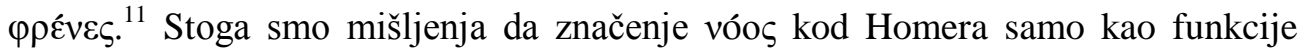

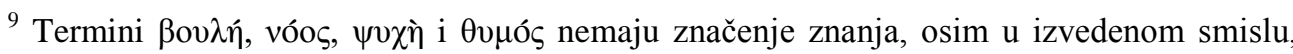

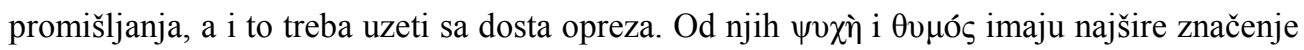
životne snage, sagledavanja skrivenog smisla događaja, i svaka bi redukcija značila nerazumevanje bogatstva njihovog obima.

${ }^{10}$ Izuzetna filološka analiza glagola voeĩv pripada Karlu von Fricu. Kritikujući Boemovo suprotsavljanje vóos-a i emocija, i odricanje glagolu voeĩv opažajnu upotrebu, on dovodi u pitanje sva tri načina razumevanja vóos u Boemovom delu: Die Seele und das Ich im Homerischen Epo.

${ }^{11}$ Analiza Darkusa pokazuje sledeće: It is significant that in Homer and the lyric poets the relationship phrenes and verbs indicating intellectual activities differs from that of noos with the same verbs. In Homer the following intellectual take place $\varphi \rho \varepsilon \sigma i$ or $\varepsilon v$ $\varphi \rho \varepsilon i$ ।

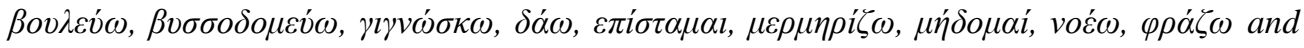
$\varphi \rho o v \varepsilon ́ \omega$. In passages where noos appears with a verb signifying intellectual activity, it is the

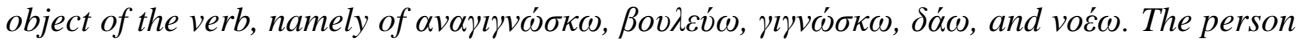
usually does not act with his noos but "knows" it. Only in one passage of Homer does the activity of a verb ( $\mu \eta \chi \alpha v \alpha \dot{o} \mu \alpha \mathrm{l})$ take place vów. Phrenes are the locations or means, in regard to verbal activity : noos is the object (Darcus, 1979 :50). 
inteligencije, a posebno u smislu racionalnosti, ipak znači njegovu redukciju na, u današnjem smislu reči, epistemološku terminologiju. Ukoliko se kod Homera vóos razume šire, kao pokretačka snaga koju dakako Homer razvija u okviru sveta čoveka i sveta bogova, kao životnu snagu sagledavanja onda je moguće objasniti dalji ,život“ ovog pojma u okviru filozofije prirode u predsokratovskoj misli, sa posebnim naglaskom na pojam voũ $\varsigma$-a kod Anaksagore. Ukoliko pak pristanemo da ovu vrstu redukcije, zaboravljamo da je vóos odlika i bogova, koji nisu mimo

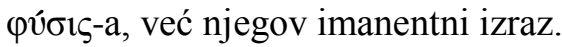

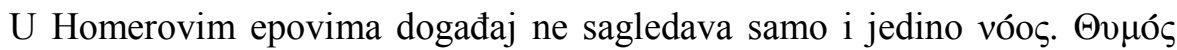
gradi najširu semantiku koja ga u okviru naše klasifikacije smešta u okvire dve grupe, naime i u životnu snagu srčanosti i u životnu snagu sagledavanja. Stoga bi njega mogli da označimo u najširem smislu kao svesnost. On se sam sabira u sebi:

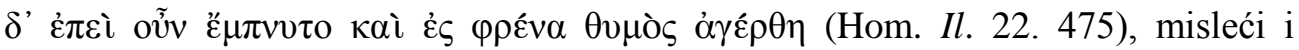
osećajući, u njemu je središte ljubavi i gneva. Čini se da on ima šire značenje i od

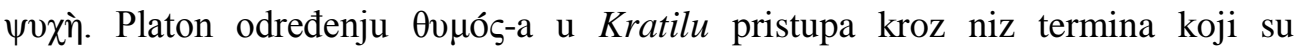
semantički vezani za stanja duše, za strasti, osećanja ili htenja, kojima Platon manje

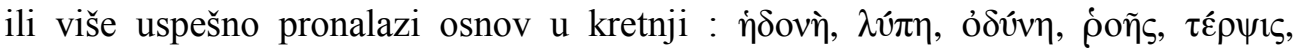

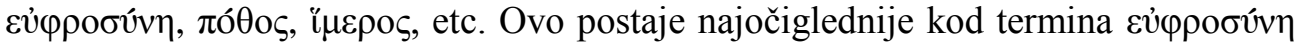

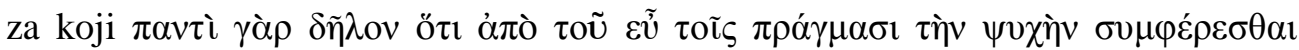

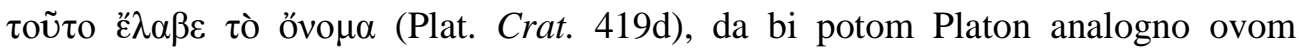

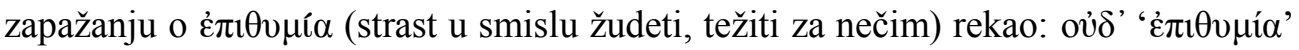

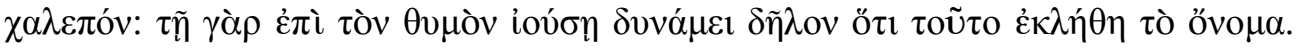

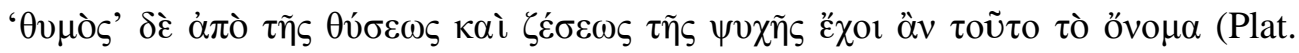

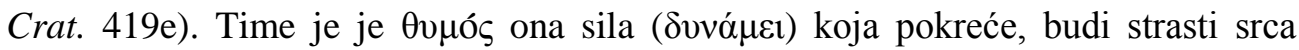

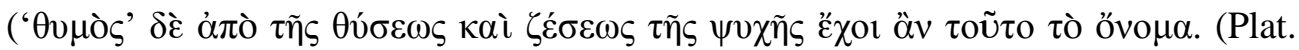

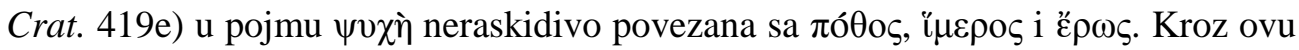
kratku Platonovu analizu pomenutih imena vidimo da su osećenja i opažaji ono što pokreće „srce“, a takvo je u tekstu koji sledi u Kratilu i htenje, mnenje pa i mišljenje.

Ali ako $\theta v \mu o ́ \varsigma$ sagledava celinu smisla događaja i sobzirom na celinu pobuđuje, a vóos pronalazi u događaju skriveno i skriva svoj naum, koju funkciju

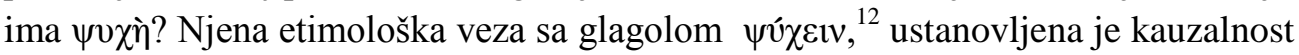
između srazmere kretanja tela i potrebe za dahom, a $\psi v \chi \chi \grave{\eta}$ vremenom, do 5.veka pre n.e., širi obim svog pojma i preuzima funkciju drugih termina. $\mathrm{O} \psi v \chi \grave{\eta} \mathrm{u}$

12 Ovakav etimološki osnov duše u disanju i izvedeno u dahu ne samo da je prisutan u homerovskom grčkom i da leži i u osnovi indoevropskog korena, već je veoma značajan za potonju filozofičnost pojma $\psi v \chi \grave{\eta}$. 
Homerovim epovima saznajemo u trenutku smrti, kada ona napušta telo ili bolje rečeno kada se ona projavljuje ( $u$ ispuštanju poslednjeg daha i/ili hlađenja tela). Istovremenost projavljivanja $\psi v \chi \grave{\eta}$ i smrti označava preinačenje tela: živo telo

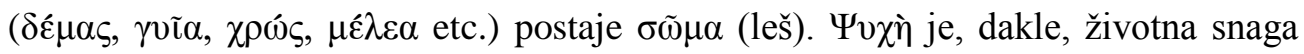
koja sagledava kraj života, sagledava smrt.

U Homerovom pesništvu ne postoji jedinstven termin za ono što mi danas podrazumevamo pod dušom, a sa prisutnom raznovrsnošću termina poklapa se odsustvo predstave o telu kao celini. Snel je pokazao da u Homerovim epovima postoji bogatstvo izraza koje je u kasnijem jeziku ako ne nestalo ono doživelo snažnu redukciju. Pojam tela u tom smislu nije izuzetak. Pokretačku snaga udova, $\gamma v \tilde{\alpha} \alpha$ i $\mu \varepsilon \hat{\ell} \varepsilon \alpha$, često zavisi od drugih reči koji uz njih stoje, a njihova semantika dakako ne seže samo do našeg određenja zglobova i mišića. $\gamma v \tilde{\alpha} \alpha$ i $\mu \varepsilon \dot{\lambda} \varepsilon \alpha$ su ono što se u Aristotelovoj psihologiji podrazumeva pod telom koje ima mogućnost života,

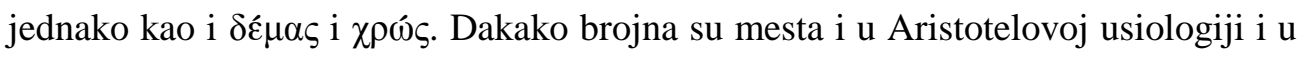
psihologiji koja raspravljaju o bivstvenosti delova, ali ona dolaze vekovima nakon Homera, kod kog ova terminološka neujednačenost nije samo posledica pesničkog izraza. Homer nema jedinstvenu predstavu živog tela. ${ }^{13}$ Tek prestankom života moguće je govoriti o telu (lešu) kao jednoj celini, ali ne više i o životnoj snazi. Stoga smo kroz terminološko određenje životne snage udova želeli da pokažemo da u Homerovom izrazu nema ontološkog dualizma u kome smo mi navikli da mislimo.

\section{ZAKLJUČAK}

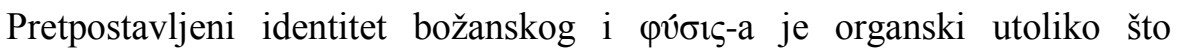
možemo reći da u Homerovom svetu božansko postoji na način prirodnog isto tako kao što i prirodno postoji na način božanskog. Ali ova gotovo istovetnost dolazi čini se iz nedeterminisanosti, a ne iz sagledavanja onog božanskog i prirodnog po sebi. Otuda je Homerov svet bogova nalik ljudskom, kako to Barnet primećuje (Burnet, 1928: 28). Ali oni nisu isprepletani tek pukom epskom slikom, niti su termini koji pripadaju životnoj snazi tek metafore. Oni su sjedinjeni događanjem sveta, sadrže promišljanje događaja, utvrđuju uzroke koji ih pokreću i u tom su smislu oni preteča filozofije Milećana. U terminima životne snage se otkriva bogatstvo izraza koje je otvorilo put filozofskog mišljenja od Talesovog stava da je $\pi \alpha ́ v \tau \alpha \pi \lambda \eta \dot{\eta} \eta$

${ }^{13}$ Odsustvo ovog jedinstva je moguće naći još u sumerskim i vavilonskim mitovima o stvaranju čoveka, tako u sumersko-akadskom epu o stvaranju Enuma eliš tako u Epu o Gilgamešu. 
$\theta \varepsilon \tilde{\omega} v\left(\mathrm{DK} 11\right.$ A22) ${ }^{14}$ koji donose i Platon i Aristotel, prvom pojmu filozofije uopšte Anaksimandrovom ö $\varepsilon \varepsilon 1 \rho o v-u$, Anksagorinom voũ $\varsigma-u$, te Aristotelovoj odredbi

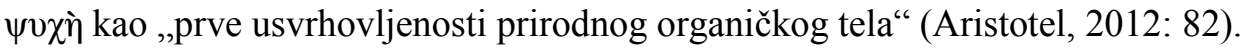

\section{Ana Miljević}

\section{DETERMINATION OF THE LIFE STRENGHT IN HOMER'S POETRY}

\section{Summary}

The gods from Homer's epics are not something opposite to or excluded from nature

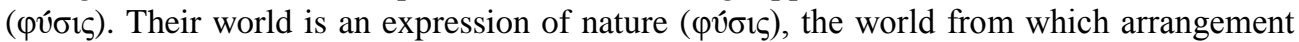
will the term cosmos arise where the geometric order will connotate a justice ( $\delta$ í $\eta)$ and its limit. Identity from the topic comes from the indetermination and not from the considering of that divine and natural in itself. The identity of divine and nature ( $\varphi v j \iota \iota)$ is substantial insofar as divine exists in the Homer world in a natural way, just as natural exists in the divine way. Moreover, we can say that Homer understands the life strength as the expression of the natural, which in his epic is nothing other than the expression of the divine. But they, the gods and the nature, are not intertwined only by a simple epic image, nor are the terms that this work forms within the frame of Homer's understanding of the life strength, just metaphors. They are united by the events of the world, contain the reflection of a living event, determine the causes that trigger events, and in that sense they are on the other side of ontological dualism. Therefore, the paper considers the thesis that the ontological dualism of the soul and body finds its roots in antiquity, and explores, through an analytical diachronic and hermeneutical method, whether and in what context we can recognize it in Homer's epic poetry. The basic thesis, of the previous studies in the literature, about Homer's psychological terminology is rejected. Instead, the work starts from the aforementioned organic unity of the divine and the nature ( $\varphi v ́ \sigma ı)$ in the terms of the life strength which the Iliad and Odyssey sing about. The question of the distinction between the soul and the body this work sees as a consequence of the metaphysical reduction of the term of life strength, and not as the original homeric question. The paper makes the classification of terms that describe the life strength on: the life strength of heartbeat $(\tilde{\eta} \tau \mathrm{\tau} \rho, \kappa \tilde{\eta} \rho$,

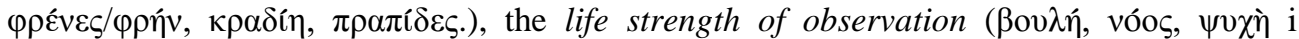
$\theta v \mu o ́ \varsigma)$ and the life strength of limbs ( $\delta \varepsilon \dot{\varepsilon} \mu \varsigma, \gamma v \tilde{\alpha} \alpha, \mu \varepsilon \dot{\lambda} \varepsilon \alpha, \chi \rho \omega \varsigma, \sigma \tilde{\omega} \mu \alpha)$. Homer's rich terminological mismatch, which shows the first explanations of movement and driving forces inseparable from the notions of life and death, allows us to understand the connection between soul $(\psi v \chi \grave{\eta})$ and life $(\zeta \omega \eta \dot{)}$ ) and to make a way to the philosophy of the nature of early Pre-socratics.

Keywords: Homer, life strength, phrenes, ethor, noos, psyche, thymos, soma, melea.

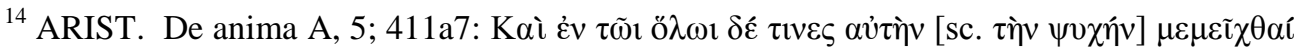

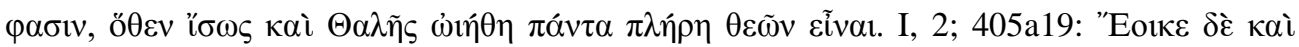

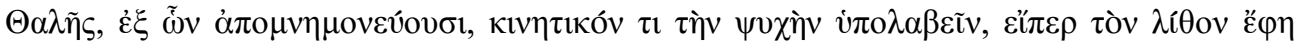

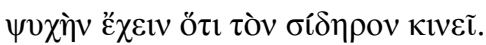




\section{LITERATURA:}

Aristotel. (1912). Poetika. Zagreb: Kr. zemaljske tiskovina.

Aristotel. (2012). O duši, Parva naturalia (prev. Blagojević, S.). Beograd: Paideia.

Aristotelis. (1896). De anima libri III. B.G. Teubner. Preuzeto sa internet adrese: https://archive.org/stream/deanimagreek189600arisuoft\#page/n3/mode/2up

Burnet, J. (1928). Greek Philosophy: Thales to Plato. London: MACMILLAN and $\mathrm{CO}$.

Darcus, S. M. (1979). A Person's Relation to $\varphi \rho \eta ́ v$ in Homer, Hesiod, and the Greek Lyric Poets. Glotta, 57, 159-173.

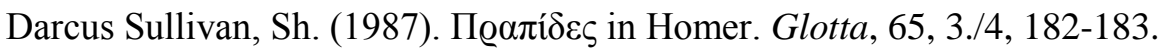

Darcus Sullivan, Sh. (1988). An Analysis of $\varphi \rho \varepsilon ́ v \varepsilon \varsigma$ in the Greek Lyric Poets (Excluding Pindar and Bacchylides). Glotta, 66, 1./2, 26-62.

Darcus Sullivan, Sh. (1996). Disturbances of the Mind and Heart in Early Greek Poetry. L'Antiquité Classique, T. 65, 31-51.

Hagen, H. (1994). Die Diskussion um die Schreibweise von Z ̃̃v(') im homerischen Epos. Glotta, 72, 1./4, 98-104.

Homer, Iliad, preuzeto sa:

http://www.perseus.tufts.edu/hopper/text?doc=Perseus\%3atext\%3a1999.01.

0133

Homer, Odyssey, preuzeto sa:

http://www.perseus.tufts.edu/hopper/text?doc=Perseus\%3atext\%3a1999.01.0135

Jahn, T. (1987). Zum Wortfeld "Seele-Geist" in der Sprache Homers. München:

C.H. Beck'sche Verlagsbuchhandlung,

Plato, Phaedo, preuzeto:

http://www.perseus.tufts.edu/hopper/text?doc=Perseus\%3atext\%3a1999.01.

0169\%3atext\%3dPhaedo

Plato, Cratylus, preuzeto sa:

http://www.perseus.tufts.edu/hopper/text?doc=Perseus\%3atext\%3a1999.01.0171\%3 atext $\% 3 \mathrm{dCrat}$.

Rode, E. (1991). Psyche: kult duše i vera u besmrtnost kod Grka. Sremski Karlovci: Izdavačka knjižarnica Zorana Stojanovića.

Snell, B. (1975). Die Entdeckung des Geistes: Studien zur Entstehung des europäischen Denkers bei den Griechen. Göttingen: Vandenhoeck \& Ruprecht.

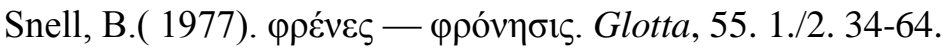

Von Fritz, K. (1943). NOO $\Sigma$ and Noein in the Homeric Poems. Classical Philology, $38,2,79-93$. 